Tạp chi Công nghệ Sinh học 14(2): 327-336, 2016

\title{
CLONING AND CHARACTERIZING CDNA SEQUENCES CODING HIGH-MANNOSE N- GLYCAN BINDING LECTINS FROM CULTIVATED RED ALGAE EUCHEUMA DENTICULATUM AND KAPPAPHYCUS STRIATUM
}

\author{
Le Dinh Hung ${ }^{1}$, Makoto Hirayama ${ }^{2}$, Kanji Hori \\ ${ }^{I}$ Nha Trang Institute of Technology Research and Application, Vietnam Academy of Science and Technology \\ ${ }^{2}$ Graduate School of Biosphere Science, Hiroshima University. Kagamiyama 1-4-4, Higashi-Hiroshima 739 - \\ 8528, Japan
}

Received: 14.11 .2014

Accepted: 29.12.2015

\section{SUMMARY}

The red algae, Eucheuma denticulatum and Kappaphycus striatum have been widely cultivated in Vietnam as a source of carrageenophytes for industry. In the past, biochemical properties of lectins isolated from these algae has been characterized and evaluated extensively. However, gene coding for such lectins isn't studied yet. In this study, their full length cDNA is amfplified using cDNA ends (RACE) methods. Sequence analysis revealed that cDNA of EDA-2 from E. denticulatum consisted of 1,158 bp containing $103 \mathrm{bp}$ of a 5'untranslated region, $248 \mathrm{bp}$ of 3'untranslated region, and 807 bp of an open reading frame; and cDNA of KSA-2 from K. striatum consisted of $1174 \mathrm{bp}$ containing $94 \mathrm{bp}$ of the 5'-untranslated region, $273 \mathrm{bp}$ of 3'untranslated region and $807 \mathrm{bp}$ of the open reading frame. The cDNA of both EDA-2 and KSA-2 encoded for a polypeptide of 269 amino acids including an initiating methionine, but differed in sequences and molecular masses. The deduced amino acid sequences of EDA-2 and KSA-2 composed of four tandem repeated domains with about 67 amino acids each. The primary structure of EDA-2 and KSA-2 is highly similar to those of the high mannose N-glycan specific lectins including OAA from cyanobacterium, BOA, MBHA and PFA from bacteria, and ESA-2, KAA-1, KAA-2 from macro red algae, which showed strong anti-HIV and anti-influenza virus activities. These results indicate that these cultivated algae are becoming promising materials for production of anti-virus reagent or functional food that can prevent virus infection in future.

Keywords: Red algae; Eucheuma denticulatum; Kappaphucus striatum; Lectin genes; EDA-2; KSA-2

\section{INTRODUCTION}

Lectins are proteins of non-immunoglobulin nature, capable of recognition and reversible binding to carbohydrate moieties of complex glycocongugates. Lectins found across a wide variety of species in nature including prokaryotes, sea corals, algae, fungi, higher plants, invertebrates and vertebrates are involved in many biological processes such as host-pathogen interactions, cellcell communication, induction of apoptosis, cancer metastasis and differentiation, targeting of cells as well as recognizing and binding carbohydrates (Sharon, Lis, 2003).

Anti-human immunodeficient virus (HIV) and/or anti-influenza virus lectins from bacteria, algae, fungi, and land plants share the common property in binding to high-mannose $N$-glycans, thereby blocking the entry of viruses into host cells through binding to the mannoside structures in the viral envelope glycoproteins, which are critical for the primary infection of viruses (Balzarini, 2006). The anti-HIV lectins from cyanobacteria (blue-green algae) and eukaryotic macroalgae are presently marked as a new antiviral agent because their HIVinhibiting activities are extremely strong compared to those from other biological groups (Ziolkowska, Wlodawer, 2006; Balzarini, 2007). One of lectins selected as a candidate for lectin-based microbicides is cyanovirin-N (CV-N) (O'Keefe et al., 2000; Boyd et al., 1997; Barrientos et al., 2006), that exhibits potent antiviral activity by blocking virus entry into the host target cells through specific and tight binding to Mano(1-2)Man-linked mannose substructures (Botos et al., 2002; Barrientos, Gronenborn, 2005; Barrientos et al., 2006; Shenoy et al., 2002). Notably, the target epitopes on Man-8/9 and binding modes for the different lectins are quite distinct (Williams et al., 2005; Ziolkowska et al., 
2006). Possible mannose-targeting lectins structurally, as well as their recognition epitopes, a novel antiviral lectin from the cyanobacterium Oscillatoria agardhii (named OAA standing for $O$. agardhii agglutinin) was investigated extensively (Koharudin et al., 2011; Koharudin, Gronenborn, 2011). Gene encoding for OAA homologous proteins (OAAHs) have recently been discovered in a number of other prokaryotic microorganisms, including cyanobacteria, proteobacteria, and chlorobacteria, as well as in eukaryotic marine red algae (Sato, Hori, 2009). Similar to OAA, OAAHs contain a sequence repeat of about 66 amino acids, with the number of repeats varying for different family members. For example, OAAH of Pseudomonas fluorescens and Herpetosiphon aurantiacus contain 133 residues and two sequence repeats, like OAA, whereas Lyngbya sp., Burkholderia oklahomensis EO147, Stigmatella aurantiaca DW4/3-1, Myxococcus xanthus, and Eucheuma serra homologs contain four sequence repeats over the length of 246-268 residues (Hori et al., 2007). In addition, several potent anti-HIV and anti-influenza virus lectins from marine macroalgae, such as griffithsin from the red alga Griffithia sp. (Mori et al., 2005), KAAs from the red alga Kappaphycus alvarezii (Sato et al., 2011a; Hirayama et al., 2016) and BCA from the green alga Boodlea coacta (Sato et al., 2011b) were investigated in more details. Although these anti-HIV lectins share both binding specificity for high-mannose $N$-glycans and repeated domain structures, they differ to each another in amino acid sequences and recognizing branched mannoside structures, which may lead to subtle difference in the degree of inhibiting activities.

The algae Kappaphycus alvarezii, K. striatum and Eucheuma denticulatum are economically important species, which were extensively cultivated either for edible purposes or as a source of carrageenophyte for industry and have been introduced in more than 20 countries for mariculture purposes (Ask, Azanza, 2002). In Vietnam, E. denticulatim and $K$. striatum cultivation began in 2005 using algal seeds imported from Bohol, Philippines. Apart from carrageenan source, these cultivated algae may provide bioactive compounds for biochemical and medicinal uses. Lectins from algae of Eucheuma and Kappaphycus genera have been isolated and well characterized and showed the novel properties in carbohydrate binding specificity with high-mannose type $N$-glycans (Hori et al., 2007; Hung et al., 2009, 2011, 2015; Sato et al., 2011a; Hirayama et al., 2016), which were distinct from those of other organisms. Therefore, they are promising sources for the development of new reagents using in biochemistry and biomedicine. In this study, genes coding lectins from these cultivated algae were isolated. The nucleotide sequences and their protein primary structures were investigated for further application of cultivated red algae, and carrageenophytes for human health purposes.

\section{MATERIALS AND METHODS}

\section{Materials}

The red algae Eucheuma denticulatum and Kappaphycus striatum were collected at Ninh Thuan province, Vietnam, in March, 2013. A small portion of the alga was stored at $-20^{\circ} \mathrm{C}$ in RNAlater solution (Invitrogen, USA) until RNA extraction. GeneRacer kit was obtained from Life Technologies (Invitrogen, USA). All other chemicals used in this study were of the highest purity available.

\section{Extract and purification RNA and mRNA from $E$. denticulatum and $K$. striatum tissues}

Total RNA of each E. denticulatum and K. striatum was extracted from 2 gram of the RNAlater-treated fresh algal tissues using the plant RNA isolation reagents (Invitrogen, USA). mRNA purification from the total RNA was performed using Oligotex ${ }^{\text {TM}}$-dT30 mRNA purification Kit (TaKaRa, Japan). RNA and mRNA quantities were determined on the NanoDrop ${ }^{\circledR}$ ND-1000 UV-Vis Spectrophotometer (Thermo Fisher Scientific). cDNAs were synthesized from 150 ng of mRNA using a GeneRacer kit (Invitrogen) according to the manufacturer's instruction.

\section{Amplification of the $3^{\prime}$ and $5^{\prime}$ cDNA ends ( 3 ' and 5'RACE) of EDA and KSA}

The first polymerase chain reaction (PCR) for amplification of the cDNA 3'end (3'RACE) was performed with 8 aliquots of a $10 \mu \mathrm{L}$ reaction mixture containing $1 \mu \mathrm{L}$ of a $10 \times$ Blend Taq buffer (Toyobo, Osaka, Japan), 2 pmol of each dNTP, 6 pmol of the GeneRacer_3'_Primer, and 2 pmol of the common-F1 primer, which was designed from the Nterminal amino acid sequence of lectins (Hung et al., 2011) (Table 1), $0.2 \mu \mathrm{L}$ of a 10-fold diluted synthesized cDNA, and 0.25 units of Blend Taq DNA polymerase (Toyobo). The reactions for 8 aliquots were performed with a $\mathrm{T}$ Gradient Thermocycler (Biometra, Göttingen, Germany) under the following conditions: denaturation at $94^{\circ} \mathrm{C}$ 
for $5 \mathrm{~min}$, follows by 30 cycles consisting of denaturation at $94^{\circ} \mathrm{C}$ for $30 \mathrm{~s}$, annealing at 8 different temperatures of $50-64^{\circ} \mathrm{C}\left(2^{\circ} \mathrm{C}\right.$ increments $)$ for $30 \mathrm{~s}$, and extension at $72^{\circ} \mathrm{C}$ for $1 \mathrm{~min}$, and the final extension step at $72^{\circ} \mathrm{C}$ for $5 \mathrm{~min}$. The PCR products in 8 aliquots were pooled, diluted to 100 fold, and then used as a template for nested PCR. The nested PCR was performed with a $50 \mu \mathrm{L}$ reaction mixture containing $5 \mu \mathrm{L}$ of a $10 \times$ Blend Taq buffer, 10 pmol of each dNTP, 2 pmol of GeneRacer_3' Nested_Primer, and 50 pmol of the degenerated primer 3 RACE_d_F2 which was designed from the conserved sequence among the high-mannose specific lectin family including ESA-2 (Hori et al., 2007) and OAA (Sato et al., 2007), $1 \mu \mathrm{L}$ of the dilution of the first PCR products, and 1.25 units of Blend Taq DNA polymerase. The nested PCR reaction was carried out by the same method of the first PCR, except for the annealing temperature of $60^{\circ} \mathrm{C}$ used. Nested PCR products were subcloned into pGEM-T Easy vector (Promega, WI, USA) and transformed into Escherichia coli DH5a competent cells. Plasmids from E. coli clones formed in selection culture mediu,m were purified using HiYield Plasmid Mini kit (RBC Bioscience, New Taipei City, Taiwan) according to the manufacturer's instruction. DNA sequencing was performed using BigDye Terminator Cycle Sequencing kit ver. 3.1 and ABI 3130xl genetic analyser (Applied Biosystems).

The first PCR of 5'RACE was performed in the same way as 3'RACE as described above, except that GeneRacer 5' Primer and the primer EDA_3'end R or KSA_3'end_R, which designed from the 3 , terminal sequence of each EDA and KSA cDNA obtained by 3'RACE (Table 1). The nested PCR was performed by the same method, except for using a 100-fold dilution of the first PCR products as a template, and the GeneRacer 5'_Nested_Primer and the primer EDA_5'RACE_R1 or KSA 5 'RACE_R1 designated from the sequence of EDA and KSA cDNA obtained by 3'RACE, as the primer pair (Table 1). Subcloning and DNA sequencing were performed as described above.

Table 1. Primer sequence used for the cDNA cloning of EDA and KSA.

\begin{tabular}{|c|c|}
\hline Primer & Sequence (from 5' to $3^{\prime}$ ) \\
\hline EDA_common F1 & AGAACCAGTGGGGAGGATCT \\
\hline EDA_3'RACE_d_F1 & AYCAITAYAAYGTIGARAAYCARTGGGG ${ }^{\text {b }}$ \\
\hline EDA_5'RACE_R1 & GCAATGTTCTTGGTAGCAGC \\
\hline EDA_5'end_F & AGAAATTCAACACCACAACT \\
\hline EDA_3'end_R & CTGCACAAAACGTAACAATATCTAT \\
\hline KSA_common F1 & AGAACCAGTGGGGAGGATCT \\
\hline KSA_3'RACE d F2 & AYCAITAYAAYGTIGARAAYCARTGGGG ${ }^{\text {b }}$ \\
\hline KSA_5'RACE R1 & AYTGRTTYTCIACRTTRTAIT ${ }^{\text {b }}$ \\
\hline KSA_5'RACE R2 & ATIGGICCYTCICCYTTRTAYTGC ${ }^{b}$ \\
\hline KSA_5'End $\mathrm{F}$ & ACCACCAGCACCGTGCTACT \\
\hline KSA_3'End R & GGGTATAGATAATAGGAATGTCC \\
\hline GeneRacer 3' Primer ${ }^{a}$ & GCTGTCAACGATACGCTACGTAACG \\
\hline GeneRacer 3' Nested Primer ${ }^{a}$ & CGCTACGTAACGGCATGACAGTG \\
\hline GeneRacer $5^{\prime}$ Primer ${ }^{a}$ & CGACTGGAGCACGAGGACACTGA \\
\hline GeneRacer $5^{\prime}$ Nested Primer ${ }^{a}$ & GGACACTGACATGGACTGAAGGAGTA \\
\hline
\end{tabular}

Note: ${ }^{a}$ These primers were inferred from the GenRacer kit (Invitrogen). ${ }^{\mathrm{b}}$ Key to symbols of the degenerated nucleotides: represents inosine; $\mathrm{Y}$ represents $\mathrm{C}$ and $\mathrm{T} ; \mathrm{R}$ represents $\mathrm{A}$ and $\mathrm{G}$.

To verify the sequence accuracy, full-length cDNA of EDA or KSA was further amplified using the high-fidelity DNA polymerase KOD Plus Neo (Toyobo), the primer pair of EDA_3'end_R and EDA_5'end_F, or
KSA_3'end_R and KSA_5'end_F, which designated from the 5 ' terminal sequence of EDA or KSA cDNA (Table 1), and a 10-fold diluted synthesized cDNAs of $E$. denticulatum or $K$. striatum as a template. Before subcloning, the 
PCR products were treated with a $10 \mathrm{x}$ Aattachment mix (Toyobo) according to the manufacturer's instruction. Subcloning and DNA sequencing were then performed as described above.

Homologous sequences were identified with the basic local alignment search tool program (BLAST). The amino acid sequence comparison was performed using the CLUSTALW 2.0 program (Larkin et al., 2007).

\section{RESULTS AND DISCUSSION}

\section{Extract and purification RNA and mRNA from $\boldsymbol{E}$. denticulatum and $K$. striatum tissues}

From 2 grams of the fresh tissues stored in RNAlater solution, total RNA and mRNA were extracted, efficiently purified and are summarized in table 2. The A260/280 ratio value of $1.8-2.0$ indicates that the RNA or mRNA is pure.

Table 2. Total RNA and mRNA yields were purified from 2 gram of the RNAlater-treated fresh algal tissues.

\begin{tabular}{lllllll}
\hline Species & $\mathbf{n g} / \boldsymbol{\mu L}$ RNA & Total RNA (ng) & A260/280 ratio & $\mathbf{n g / \mu L ~ m R N A}$ & $\begin{array}{c}\text { Total mRNA (ng) } \\
\text { A260/280 } \\
\text { ratio }\end{array}$ \\
\hline E. denticulatum & 118.6 & 47.76 & 2.18 & 3.7 & 177.0 & 2.2 \\
K. striatum & 159.9 & 63.960 & 2.08 & 3.6 & 288.0 & 2.1 \\
\hline
\end{tabular}

Primary structure of lectins EDA and KSA and comparison analysis to other proteins

cDNA cloning of lectin EDA and KSA were performed by $5^{\prime}$ and 3 'RACEs as described in the Materials and Methods (Figure 1). The obtained full-length cDNA of EDA lectin consisted of $1,158 \mathrm{bp}$ containing $103 \mathrm{bp}$ of a 5 'untranslated region (5'UTR), $807 \mathrm{bp}$ of an open reading frame
(ORF), and 248 bp of 3'UTR (Figure 2). ORF coded a polypeptide of 269 amino acids including the initiating methionine amino acid. The calculated molecular mass of the deduce amino acid sequence from EDA cDNA was 27.834.19 Da, similar to that of EDA-2 (27,834.2 Da) determined by ESI-MS methods (Hung et al., 2015). Thus we can concluded that the isolated cDNA encoding EDA-2.

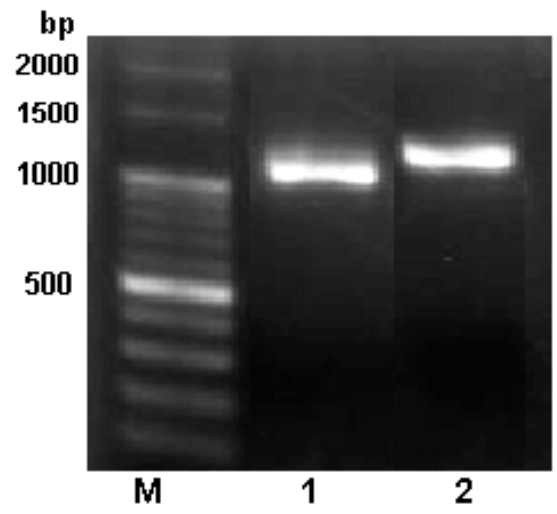

Figure 1. PCR products electrophoresis separated on 1\% agarose. M: 100 bp DNA Ladder (Toyobo, Japan). 1: 1158 bp fragment of EDA. 2: 1174 bp fragment of of KSA. 
Tạp chi Công nghệ Sinh học 14(2): 327-336, 2016

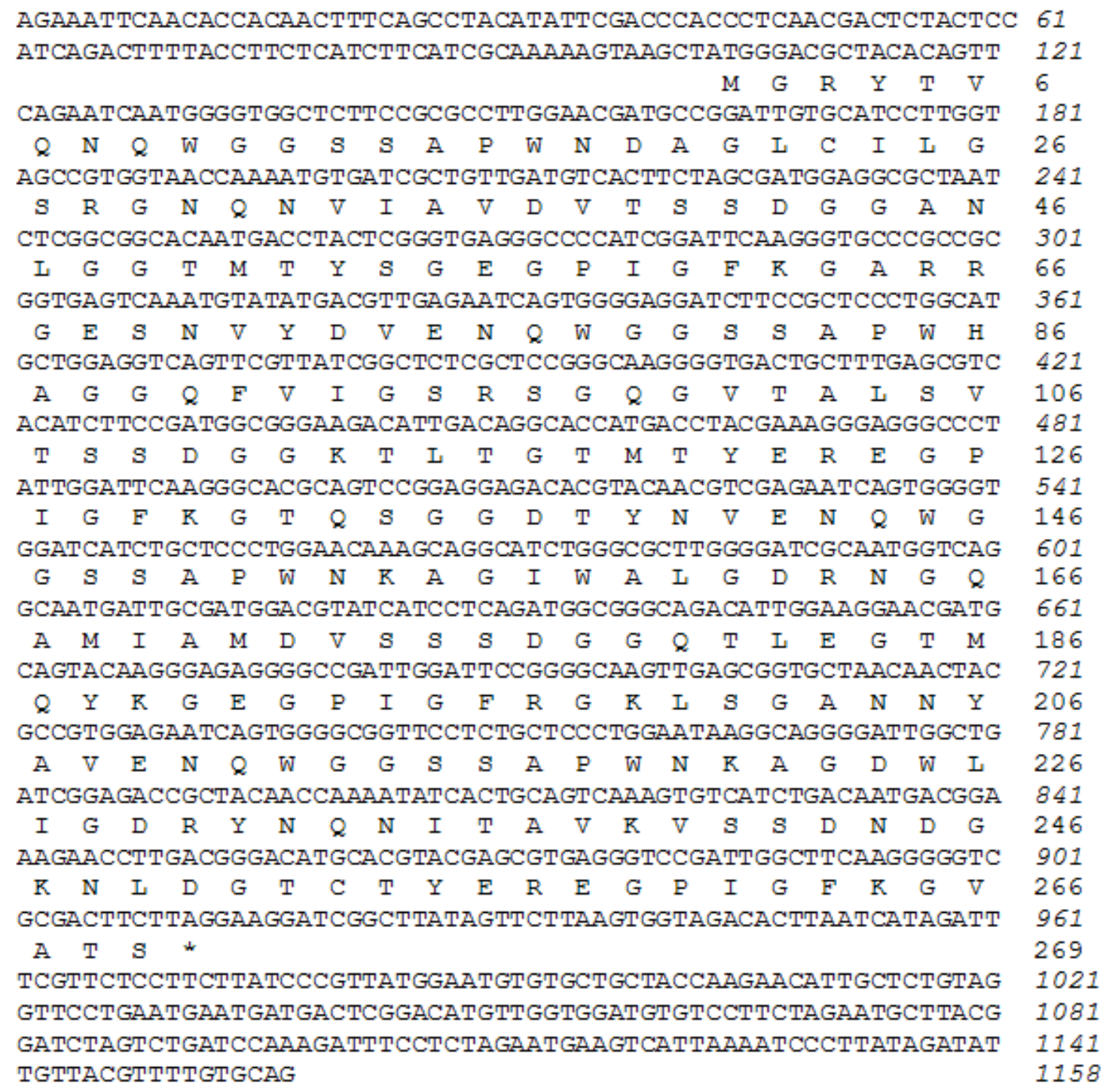

Figure 2. Nucleotide and deduced amino acid sequences of EDA-2, a lectin from $E$. denticulatum (registered as accession number LC057379 in GenBank). The stop codon TAG is shown as an asterisk. The italicized and nonitalicized numbers represent the positions of nucleotides and amino acids, respectively.

The full-length cDNA of KSA lectin consisted of 1174 bp containing 94 bp of $5^{\prime}$-untranslated region (UTR), $273 \mathrm{bp}$ of $3^{\prime}$ UTR, and $807 \mathrm{bp}$ of the open reading frame (ORF) and encoded a polypeptide of 269 amino acids including an initiating methionine (Figure 3). The molecular mass of the deduce amino acid sequence from KSA lectin cDNA was calculated as $28,021.4 \mathrm{Da}$, which was similar to that of KSA-2 determined by ESI-MS method (28,021.3 Da) (Hung et al., 2011). The $20 \mathrm{~N}$-terminal amino acid sequence of both EDA-2 and KSA-2, determined by Edman degradation (Hung et al., 2011) was also found in the deduced amino acid sequences from isolated cDNAs. The deduced amino acid sequences of both EDA-2 and KSA-2 have four tandem repeated domains and each domain consists of 67 amino acids. Four domains of EDA-2 shared $47 \%$ sequence identity (Figure 4a), whereas those of KSA-2 shared $44.8 \%$ sequence identity (Figure 4b). Clusters of identical amino acids among the four repeated domains of both lectins were located on both $\mathrm{N}$ - and C-terminal regions of each domain. The seven other homologous amino acid sequences were found in database, including one from the cyanobacterium, Oscillatoria 
agardhii (OAA) (132 aa) (P84330), three from bacteria, Burkholderia oklahomensis EO147 (BOA) (276 aa) (ZP_02360833), Pseudomonas fluorescens Pf0-1 (PFA) (133 aa) (YP 346241) and Myxococcus xanthus (MBHA) (267 aa) (M13831), and three lectins from marine red algae, Eucheuma serra (ESA2) (268 aa) (P84331), Kappaphycus alvarezii (KAA1) (267 aa) (LC007080) and KAA-2 (268 aa) (LC007081). All of them contain four tandem repeated homologous domains of about 67 amino acids, except $O$. agardhii and $P$. fluorescens, which possess only two tandem repeated homologous domains (Figure 5). The similarity degrees between KSA-2, ESA-2, KAA-1, KAA-2, MBHA and BOA amino acid sequences with EDA-2 were 95.2, 95.2, 94.0, 94.8, 59.0 and $56.8 \%$, respectively, whereas sequence of OAA from $O$. agardhii and PFA from $P$. fluorescens (each 132 residues in the N-terminal portions) showed a considerable similarity to EDA-2 with 61.4 and $63.6 \%$, respectively.

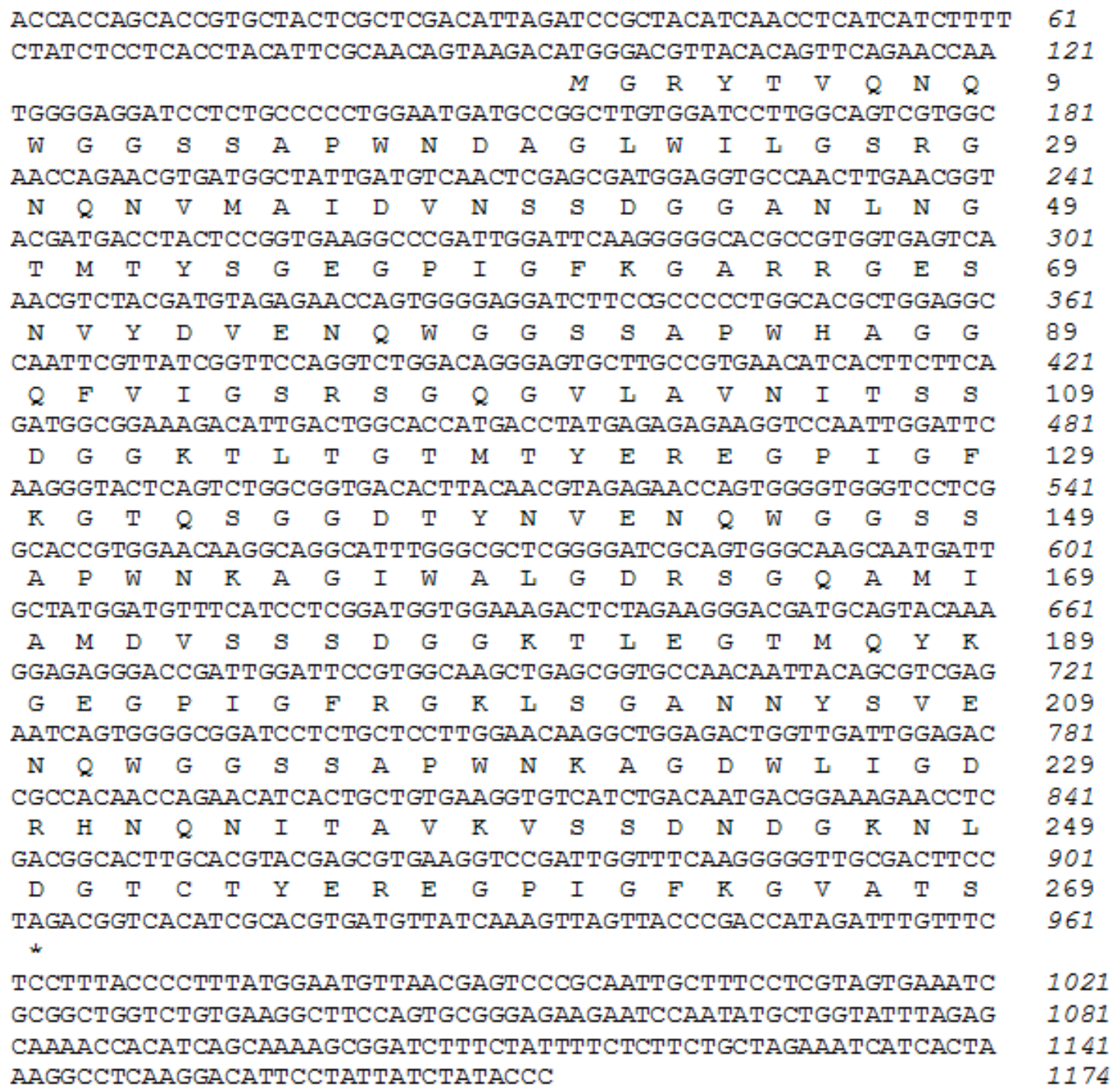

Figure 3. Nucleotide and deduced amino acid sequences of KSA-2, a lectin from $K$. striatum (registered as accession number LC057282 in GenBank). The stop codon TAG is shown as an asterisk. The italicized and nonitalicized numbers represent the positions of nucleotides and amino acids, respectively. . 
Tạp chi Công nghệ Sinh học 14(2): 327-336, 2016

$\mathrm{EDA}-2$ (a)

GRYTVQNQWGGSSAPWNDAGLCILGSRGNQNVIAVDVTSSDGGANLGGTMTYSGEGPIGFKGARRGES (1-68) NVYDVENQWGGSSAPWHAGGQFVIGSRSGQGVTALSVTSSDGGKTLTGTMTYEREGPIGEKGTQSGG (69-135) DTYNVENQWGGSSAPWNKAGIWALGDRNGQAMIAMDVSSSDGGQTLEGTMQYKGEGPIGFRGKLSGA (136-202) NNYAVENOWGGSSAPWNKAGDWLIGDRYNONITAVKVSS DNDGKNLDGTCTYEREGPIGFKGVATS

$(203-268)$

KSA-2 (b)

GRYTVQNQWGGSSAPWNDAGLWILGSRGNQNVMAIDVNSSDGGANLNGTMTYSGEGPIGFKGARRGES (1-68)

NVYDVENOWGGSSAPWHAGGQFVIGSRSGQGVLAVNITSSDGGKTLTGTMTYEREGPIGFKGTQSGG (69-135)

DTYNVENQWGGSSAPWNKAGIWALGDRSGQAMIAMDVSSSDGGKTLEGTMQYKGEGPIGFRGKLSGA (136-202)

NNYSVENQWGGSSAPWNKAGDWLI GDRHNQNITAVKVSSDNDGKNLDGTCTYEREGPIGFKGVATS (203-268)

Figure 4. Comparison of the four tandem-repeated domains of lectin EDA-2 (a) and KSA-2 (b), respectively. Identical amino acids among the four repeated domains in the lectin molecules are indicated in red color.

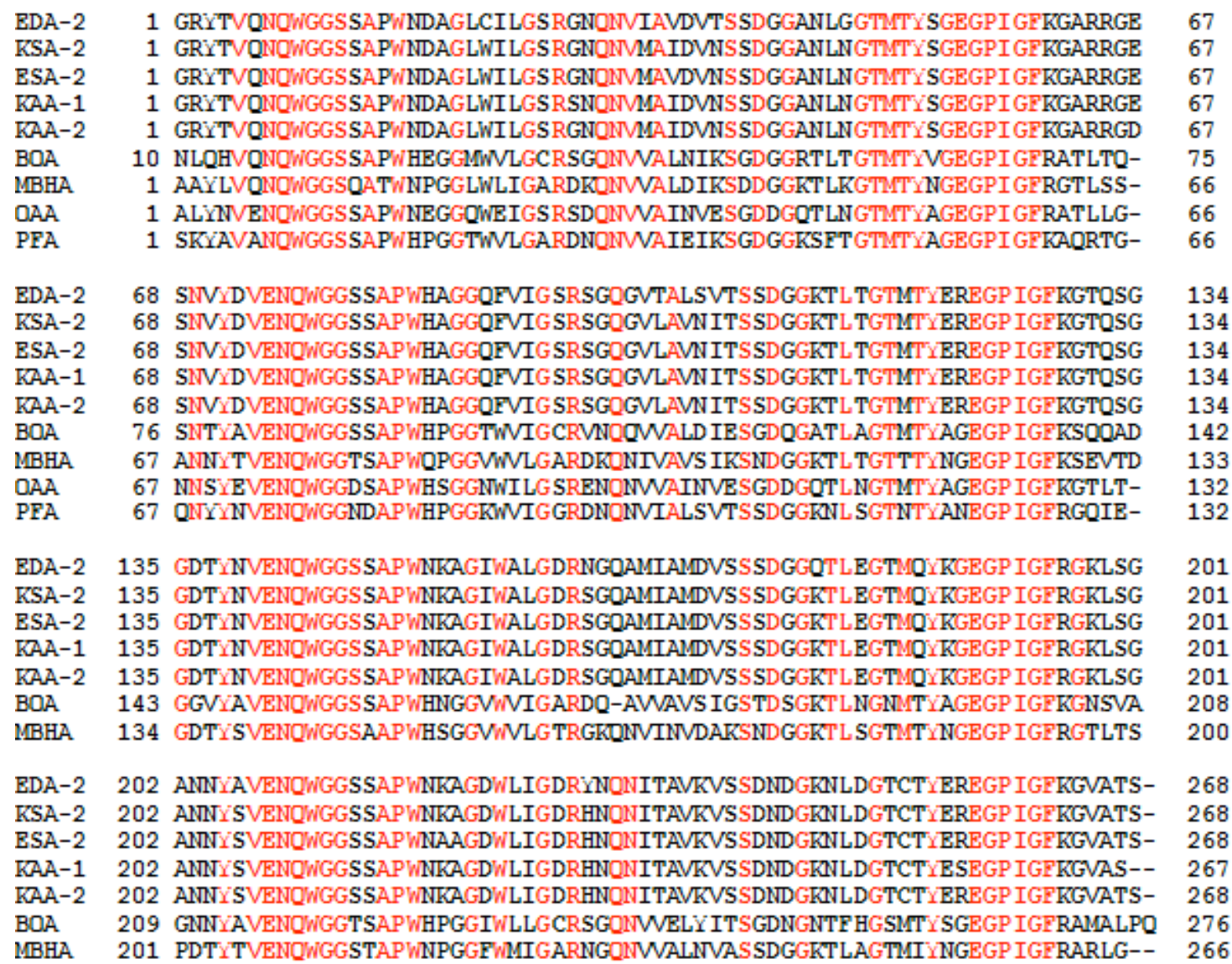

Figure 5. Multiple alignments of EDA-2 and KSA-2 with related proteins. Multiple sequence alignments were carried out using the CLUSTALW 2.0 program (Larkin et al., 2007). The identical amino acids were indicated in red color. The following sequences were obtained from GenBank: O. agardhii (OAA) (P84330); B. oklahomensis EO147 (BOA) (ZP_02360833); $P$. fluorescens Pf0-1 (PFA) (YP 346241); M. xanthus (MBHA) (YP 635174); E. serra (ESA-2) (P84331); K. alvarezii (KAA-1) (LC007080) and KAA-2 (LC007081).

The deduced amino acid sequence of lectins EDA-2 and KSA-2 shares similar structure and carbohydrate specificity. These lectins presents in lower organisms at various taxonomies and living 
environments such as ESA-2, KAA-1 and KAA-2 from marine red algae, MBHA from a soil bacterium, OAA from a fresh water cyanobacterium, BOA and PFA from bacteria. The lectins in this family are commonly monomeric proteins composed of either two or four tandem repeats of homologous domains of about 67 conserved amino acids, depending on the organism. The significance difference in biological and evolutionary of the number of repeated domains is currently unknown. However, their sequence similarities suggest that these proteins may also share lectin domains that have a binding affinity for high-mannose $\mathrm{N}$-glycans, as ESA-2 (Hori et al., 2007), KSA-2 (Hung et al., 2011), EDA-2 (Hung et al., 2015), KAA-2 (Sato et al., 2011a; Hirayama et al., 2016), OAA (Sato et al., 2007), BOA (Whitley et al., 2013), PFA and MBHA (Sato et al., 2012; Koharudin et al., 2012), which showed strong antiHIV and anti-influenza virus activities. From sequence comparison, it is also speculated that the highly conserved segments in both $\mathrm{N}$-terminal and C-terminal regions may be involved in the carbohydrate binding. Although the high-mannose $N$-glycan recognition profile of EDA-2 (Hung et al., 2015) and KSA-2 (Hung et al., 2011) was slightly differed from those of the high-mannose binding cyanobacterial lectins such as CV-N (Botos et al., 2002), MVL (Williams et al., 2005) and SVN (Bokesch et al., 2003), EDA-2 and KSA-2 has no sequence similarity with these cyanobacterial lectins, except for OAA (Sato et al., 2007). The strict specificity for high-mannose oligosaccharides with very high binding affinities seems to be a common feature among lectins from lower organisms such as cyanobacteria and algae.

\section{CONCLUSION}

cDNAs encoding for lectins EDA-2 and KSA-2 were successful isolated from E. denticulatum and $K$. striatum algae cultivated in Vietnam.. Analysis of deduced amino acid sequences of EDA-2 and KSA-2 DNA indicated that the tandem repeated homologous domains in their amino acid sequence resembled those of lectins presenting in lower organisms, which showed strong anti-HIV and anti-influenza virus activities. Therefore, these algae might be promising materials for production of anti-virus reagent or functional food that can prevent virus infection in future. Clarifying the structural basis of the recognition mode of the carrageenophyte lectins should contribute to demonstrate the biological function(s) as well as application of this lectin group.

Acknowledgements: This research was supported by Vietnam National Foundation for Science and Technology Development (NAFOSTED) under grant number 106.05-2011.35 and 106-YS.06-2015.16.

\section{REFERENCES}

Ask EI, Azanza RV (2002) Advances in cultivation technology of commercial eucheumatoid species: a review with suggestions for future research. Aquaculture 206: 257-277.

Balzarini J (2006) Inhibition of HIV entry by carbohydrate-binding proteins. Antiviral Res 71: 237-247.

Balzarini J (2007) Carbohydrate-binding agents: a potential future cornerstone for the chemotherapy of enveloped viruses? Antivir Chem Chemother 18: 1-11.

Barrientos LG, Gronenborn AM (2005) The highly specific carbohydrate-binding protein cyanovirin-N: structure, anti-HIV/Ebola activity and possibilities for therapy. Mini Rev Med Chem 5: 21-31.

Barrientos LG, Matei E, Lasala F, Delgado R, Gronenborn AM (2006) Dissecting carbohydrate-cyanovirin-N binding by structureguided mutagenesis: functional implications for viral entry inhibition. Protein Eng Des Sel 19: 525-535.

Bokesch HR, O'Keefe BR, McKee TC, Pannell LK, Patterson GM, Gardella RS, Sowder RC, Turpin J, Watson K, Buckheit RW, Boyd MR (2003) A potent novel antiHIV protein from the cultured cyanobacterium Scytonema varium. Biochemistry 42:2578-2584.

Botos I, O'Keefe BR, Shenoy SR, Cartner LK, Ratner DM, Seeberger PH, Boyd MR, Wlodawer A (2002) Structures of the complexes of a potent anti-HIV protein cyanovirin$\mathrm{N}$ and high mannose oligosaccharides. J Biol Chem 277: 34336-34342.

Boyd MR, Gustafson KR, Mcmahon JB, Shoemaker RH, O'Keefe BR, Mori T, Gulakowski RJ, Wu L, Rivera MI, Laurencot CM, Currens MJ, Cardellina IIJH, Buckheit JrRW, Nara PL, Pannell LK, Sowder IIRC, Henderson LE (1997) Discovery of cyanovirin-N, a novel human immunodeficiency virus inactivating protein that binds viral surface envelope glycoprotein gp120: potential applications to microbicide development. Antimicrob Agents Chemother 41: 1521-1530.

Hirayama M, Shibata H, Imamura K, Sakaguchi T, Hori K (2016) High-mannose specific lectin and its recombinants from a Carrageenophyta Kappaphycus alvarezii represent a potent anti-HIV activity through high-affinity binding to the viral envelope glycoprotein gp120. Mar Biotechnol 18: 144-160. 
Hori K, Sato Y, Ito K, Fujiwara Y, Iwamoto Y, Makino H, Kawakubo A (2007) Strict specificity for high-mannose type $\mathrm{N}$-glycans and primary structure of a red alga Eucheuma serra lectin. Glycobiology 17: 479-491.

Hung LD, Sato T, Shibata H, Hori K (2009) Biochemical comparison of lectins among three different color strains of the red alga Kappaphycus alvarezii. Fish Sci 75: 723-730.

Hung LD, Sato Y, Hori K (2011) High-mannose N-glycanspecific lectins from the red alga Kappaphycus striatum (Carrageenophyte). Phytochemistry 72: 855-861.

Hung LD, Hirayama M, Ly BM, Hori K (2015) Purification, primary structure and biological activity of high-mannose $N$-glycan-specific lectin from the cultivated Eucheuma denticulatum. J Appl Phycol 27: 1657-1669.

Koharudin LM, Furey W, Gronenborn AM (2011) Novel fold and carbohydrate specificity of the potent anti-HIV cyanobacterial lectin from Oscillatoria agardhii. J Biol Chem 286: 1588-1597.

Koharudin LM, Gronenborn AM (2011) Structural basis of the anti-HIV activity of the cyanobacterial Oscillatoria agardhii agglutinin. Structure 19: 1170-1181.

Koharudin LMI, Kollipara S, Aiken C, Gronenborn AM (2012) Structural insights into the Anti-HIV activity of the Oscillatoria agardhii agglutinin homolog lectin family. $J$ Biol Chem 287: 33796-33811.

Larkin MA, Blackshields G, Brown NP, Chenna R, McGettigan PA, McWilliam $\mathrm{H}$, Valentin F, Wallace IM, Wilm A, Lopez R, Thompson JD, Gibson TJ, Higgins DG (2007) Clustal W and Clustal X version 2.0. Bioinformatics 23: 2947-2948.

Mori T, O'Keefe BR, Sowder RC, Bringans S, Gardella R, Berg S, Cochran P, Turpin JA, Buckheit RWJr, McMahon $\mathrm{JB}$, Boyd MR (2005) Isolation and characterization of griffithsin, a novel HIV-inactivating protein, from the red alga Griffithsia sp. J Biol Chem 280: 9345-9353.

O'Keefe BR, Shenoy SR, Xie D, Zhang W, Muschik JM, Currens MJ, Chaiken I, Boyd MR (2000) Analysis of the interaction between the HIV-inactivating protein cyanovirin$\mathrm{N}$ and soluble forms of the envelope glycoproteins gp120 and gp41. Mol Pharmacol 58: 982-992.

Sato Y, Okuyama S, Hori K (2007) Primary structure and carbohydrate-binding specificity of a potent anti-HIV lectin isolated from the filamentous cyanobacterium, Oscillatoria agardhii. J Biol Chem 282: 11021-11029.
Sato T, Hori K (2009) Cloning, expression, and characterization of a novel anti-HIV lectin from the cultured cyanobacterium, Oscillatoria agardhii. Fish Sci 75: 743-753.

Sato Y, Morimoto K, Hirayama M, Hori K (2011a) High mannose-specific lectin (KAA-2) from the red alga Kappaphycus alvarezii potently inhibits influenza virus infection in a strain-independent manner. Biochem Biophys Res Commun 405: 291-296.

Sato Y, Hirayama M, Morimoto K, Yamamoto N, Okuyama S, Hori K (2011b) High mannose-binding lectin with preference for the cluster of $\alpha 1-2$-mannose from the green alga Boodlea coacta is a potent entry inhibitor of HIV-1 and influenza viruses. $J$ Biol Chem 286: 1944619458.

Sato Y, Morimoto K, Kubo T, Yanagihara K, Seyama T (2012) High mannose-binding antiviral lectin PFL from Pseudomonas fluorescens Pf0-1 promotes cell death of gastric cancer cell MKN28 via interaction with $\alpha 2$-integrin. PLos One 7, e45922.

Sharon N, Lis H (2003) Lectins, second ed. Kluwer Academic Publishers, The Netherlands.

Shenoy SR, Barrientos LG, Ratner DM, O'Keefe BR, Seeberger PH, Gronenborn AM, Boyd MR (2002) Multisite and multivalent binding between cyanovirin- $\mathrm{N}$ and branched oligomannosides: calorimetric and NMR characterization. Chem Biol 9: 1109-1118.

Whitley MJ, Furey W, Kollipara S, Gronenborn AM (2013) Burkholderia oklahomensis agglutinin is a canonical twodomain OAA-family lectin: structures, carbohydrate binding, and anti-HIV activity. FEBS J 280: 2056-2067.

Williams DCJr, Lee JY, Cai M, Bewley CA, Clore GM (2005) Crystal structures of the HIV-1 inhibitory cyanobacterial protein MVL free and bound to $\mathrm{Man}_{3} \mathrm{GlcNAc}_{2}$ : structural basis for specificity and high affinity binding to the core pentasaccharide from $N$-linked oligomannoside. J Biol Chem 280: 29269-29276.

Ziólkowska NE, O'Keefe BR, Mori T, Zhu C, Giomarelli B, Vojdani F, Palmer KE, McMahon JB, Wlodawer A (2006) Domains wapped structure of the potent antiviral protein Griffithsin and its mode of carbohydrate binding. Structure 14: 1127-1135.

Ziólkowska NE, Wlodawer A (2006) Structural studies of algal lectins with anti-HIV activity. Acta Biochim Pol 53: 617-626. 


\title{
NHÂN DÒNG VÀ NGHIÊN CỨU ĐẶC ĐIỂM CÁC cDNA MÃ HÓA CÁC LECTIN LIÊN KẾT N- GLYCAN DANG MANNOSE CAO TỪ HAI LOÀI TẢO ĐỎ EUCHEUMA DENTICULATUM VÀ KAPPAPHYCUS STRIATUM
}

\author{
Lê Đình Hùng ${ }^{1, \bowtie}$, Makoto Hirayama ${ }^{2}$, Kanji Hori ${ }^{2}$ \\ ${ }^{I}$ Viện Nghiên cứu và Úng dụng công nghệ Nha Trang, Viện Hàn lâm Khoa hoc và Công nghệ Việt Nam \\ ${ }^{2}$ Graduate School of Biosphere Science, Hiroshima University. Kagamiyama 1-4-4, Higashi-Hiroshima 739 - \\ 8528, Japan
}

\section{TÓM TẮT}

Tảo đỏ, Eucheuma denticulatum and Kappaphycus striatum đang được nuôi trồng rộng rãi ở Việt nam cũng như là một nguồn nguyên liệu để sản xuất carrageenan. Lectin từ mẫu tảo này đã được tinh chế và xác định các tính chất hóa sinh. Tuy nhiên, gen mã hóa lectin của các mẫu tảo hầu như chưa được nghiên cứu. Trong nghiên cứu này, trình tự cDNA chứa chiều dài hoàn chỉnh của gen mã hóa các lectin của carrageenophyte đã được phân lập sử dụng phương pháp khuyếc đại nhanh các đầu tận cùng cDNA (RACE) Phân tích trình tự toàn bộ. $\mathrm{cDNA}$ của EDA-2 và KSA-2 cho thấy các gen này đều mã hóa cho một polypeptide chứa 269 amino acid bao gồm trình tự khởi đầu mã hóa cho methionine, nhưng lại khác nhau về trong trình tự amino acid và trọng lượng phân tử. cDNA of EDA-2 có kích thước 1158 bp mang 103 bp của đoạn 5' không dịch mã, 248 bp của đoạn 3' không dịch mã và 807 bp của một khung đọc mở. cDNA of KSA-2 có kích thước 1174 bp bao gồm 94 bp của đoạn 5' không dịch mã, 273 bp của đoạn 3' không dịch mã và một khung đọc mở $807 \mathrm{bp}$. Trình tự amino acid suy diễn từ cDNA của cả hai lectin nêu trên đều chứa 4 vùng lặp lại nối tiếp nhau có khoảng 67 amino acid. Cấu trúc bậc 1 của EDA-2 và KSA-2 có sự tương đồng cao với các cấu trúc của lectin liên kết $\mathrm{N}$-glycan dạng mannose cao bao gồm $\mathrm{OAA}$ từ vi tảo, $\mathrm{BOA}, \mathrm{MBHA}$ và $\mathrm{PFA}$ từ vi khuẩn, và ESA-2, KAA-1 and KAA-2 từ tảo đỏ, các lectin này đã được chứng minh là có hoạt tính kháng virus HIV và virus cúm mạnh. Các kết quả nghiên cứu thu được đã cho thấy các mẫu tảo nuôi trồng có thể trở thành thuốc kháng virus mới hoặc làm thực phẩm chức năng tăng cường ngăn chặn sự lây nhiểm của virus trong tương lai.

Tù khóa:, Tảo đỏ, Eucheuma denticulatum, Kappaphycus striatum, gen mã hóa lectin EDA-2; KSA-2

\footnotetext{
${ }^{凶}$ Author for correspondence: Tel: +84-583521133; Fax:+84-583521847; E-mail: ledinhhungims@yahoo.co.uk
} 